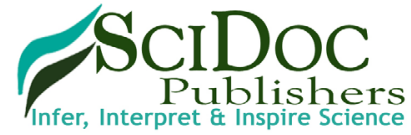

\section{Possible Protective Effect of Pumpkin Seed Oil against Sodium Nitrite in Rats; A Biochemical and Genetic Study}

\author{
Research Article
}

Ali DM' ${ }^{1}$, Abdelzaher $\mathrm{WY}^{2 *}$

${ }^{1}$ Forensic Medicine \& Toxicology Department, Faculty of Medicine, Minia University, Egypt.

${ }^{2}$ Pharmacology Department, Faculty of Medicine, Minia University, Egypt.

\title{
Abstract
}

Objective: The aim of our study was to test the protective effect of pumpkin seed oil against sodium nitrite toxicity in rats. Methods: Forty eight adult male albino rats were divided into 4 groups. The rats were administered daily $100 \mathrm{mg} / \mathrm{kg} / \mathrm{day}$ sodium nitrite in presence/absence of $1.5 \mathrm{ml} / \mathrm{kg} /$ day pumpkin seed oil for 5 weeks.

Results: The results indicated that sodium nitrite induced oxidative stress, lipids profile disorders, DNA damage and chromosomal abnormalities. The pumpkin seed oil has antioxidant effect; it improved levels of total antioxidant capacity, malondialdehyde and lipids profile. It also has antimutagenic effect; it decreased the DNA damage and structural chromosomal abnormalities.

Conclusion: Pumpkin seed oil can ameliorate the toxic effects induced by sodium nitrite.

Keywords: Chromosomal Aberrations, DNA Damage; Pumpkin Seed Oil; Sodium Nitrite.

\section{Introduction}

Sodium nitrite $\left(\mathrm{NaNO}_{2}\right)$ is an inorganic compound, slightly yellowish crystalline powder that is highly soluble in water. Its chemical formula is $\mathrm{NaNO}_{2}$. It is used in many industries such as rubber chemicals, in photography, bleaching fibers, dyeing and printing textile fabrics, as a corrosion inhibitor and a laboratory reagent [1]. It has been reported that Sodium nitrite has many medical uses as in pulmonary hypertension [2], myocardial infarction [3] and as an antidote for cyanide poisoning [4], an intestinal relaxant [5] and a bronchial dilator [6].

It is also one of the common food additives in preserving of refrigerated meats and meat products to prevent botulism by inhibition of iron-sulfur clusters and hence inhibiting the growth of Clostridium botulinum spores in preserved meats. It also prevents rancidity by inhibition of lipid peroxidation [7].

Nitrate and nitrite can be found in soil from oxidation of ammonia which results from decomposition of inorganic nitrogenous fertilizers and organic nitrogenous wastes. Then, the plants absorb nitrite from soil during their growth. Nitrite can also be formed in distribution pipes of drinking water by action of Nitrosomonas bacteria in stagnant water or by chloramination of water [8].

Humans are continuously exposed to $\mathrm{NaNO}_{2}$ from different sources. In general, vegetables and cured meat are considered the major sources of nitrate and nitrite in the diet. The daily intake of nitrite in human is about 0.3 to $2.6 \mathrm{mg}$ /day, mainly from meat products [9]. Although $\mathrm{NaNO}_{2}$ is used in inhibition of bacterial growth, its high amounts result in human toxicity. Sodium nitrite's LD50 in rats is $180 \mathrm{mg} / \mathrm{kg}$ and its human LD50 is $71 \mathrm{mg} / \mathrm{kg}$ that means consumption of $4.615 \mathrm{~g}$ for $65 \mathrm{~kg}$ person lead to death. [10].

Nitrite oxidizes heme iron from ferrous to ferric state leading to methemoglobinemia which results in deficiency of oxygen available to body tissues [11]. Other toxic effect of $\mathrm{NaNO}_{2}$ is contributed to its conversion into the body to nitrosonium ions which reacts with amines and amides of the foods in the stomach to produce nitrosamines and nitrosamides respectively [12]. These compounds lead to lipid peroxidation and cause oxidative stress, which are risky to different organs in the body [13]. It has been reported that Diethylnitrosamine produce free radicals in the rat liver tissue [14].

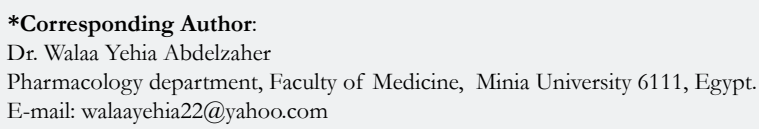

Citation: Ali DM, Abdelzaher WY (2017) Possible Protective Effect of Pumpkin Seed Oil against Sodium Nitrite in Rats; A Biochemical and Genetic Study. Int J Clin Pharmacol Toxicol. 6(2), 262-269. doi: http://dx.doi.org/10.19070/2167-910X-1700044

Copyright: Abdelzaher WY $\mathbf{Y}^{\odot}$ 2017. This is an open-access article distributed under the terms of the Creative Commons Attribution License, which permits unrestricted use, distribution and reproduction in any medium, provided the original author and source are credited. 
Many cases of toxicities or even death in humans and animals from nitrate and nitrite have been reported [15-17]. Hence, efforts for reduction of nitrite level in the environment are essential for protection of human health.

The pumpkin (Cucurbita spp.) is a common conventional food in many countries. It has been recognized since $16^{\text {th }}$ century. Pumpkin seeds contain about 42 to $54 \%$ oil. Pumpkin seed oil is strong dichromatic viscous oil. It is chemically characterized by Procida et al., Rezig et al., and Stevenson et al., [18-20]. 98\% of pumpkin seed oil is fatty acids (mainly; linoleic acid, oleic acid, palmitic acid and stearic acid). It has high amounts of antioxidant vitamins as $\alpha$ - and $\gamma$-tocoferol, $\beta$ carotene and vitamin E [20]. Pumpkin seed oil also contains phenolic compounds such as vanillic acid, tyrosol and vanillin and high levels of selenium and lutein [21]. In comparison to other seed oil, it is rich in squalene which is a carbon organic compound that has many commercial uses [22]. It is an affluent source of phytosterols and proteins [23].

Presence of all these constituents in pumpkin seed oil, clarify their useful and valuable effects to human health. Nowadays, it is used in treatment of many diseases as diabetes [24], hypertension, hypercholesterolemia [25], symptomatic micturition disorders [26] and arthritis [27]. Elfiky et al., has reported that pumpkin has anti-mutagenic activities [28]. Moreover, it has anticancerous effect due to presence of Lipoxygenases' inhibitors which has antiproliferative action [29].

The aim of the present study was to test the role of pumpkin seed oil in prevention and/or reduction of toxicity associated with oxidative stress induced by $\mathrm{NaNO}_{2}$ after chronic administration in adult male albino rats.

\section{Materials and Methods}

\section{Chemicals}

Sodium nitrite was purchased from Sigma Aldrich (Saint Louis, MO, USA) and was applied as a freshly prepared solution. Pumpkin seed oil was purchased from Nutra Manufacturing, Inc, USA and was applied as oil. Total antioxidant capacity (TAC) (Biodiagnostic, Egypt), Cholesterol kit (Biomed diagnostic, Egypt), Triglycerides kit (Biodiagnostic, Egypt), HDL kit (Spectrum, Egypt).

\section{Animals}

Forty eight adult healthy male Wistar albino rats weighing 180-200 gm, were purchased from the National Research Center, Cairo, Egypt. Rats were used after one week for proper acclimatization to the animal house conditions $\left(12 \mathrm{~h}\right.$ lighting cycle, $25 \pm 2{ }^{\circ} \mathrm{C}$ temperature and $45 \pm 5 \%$ humidity) and had free access to standard rodent chow; drinking water and specific rats chow diet (obtained from El-Nile Company for chow and chicken). Procedures involving animals and their care were conducted in conformity with the protocols of the Research Advisory Ethical Committee of Faculty of Medicine, Minia University, Egypt.

\section{Experimental Procedures}

The rats were randomly divided into 4 groups with 12 rats in each one:
Group I (control group): was received the standard diet only without any treatment.

Group II (pumpkin seed oil group): was received the standard diet with pumpkin seed oil at a dose of $1.5 \mathrm{ml} / \mathrm{kg}$ b.w. (body weight)/ day, according to Eraslan et al., [30].

Group III (sodium nitrite group): was received the standard diet with sodium nitrite at a dose of $100 \mathrm{mg} / \mathrm{kg}$ b.w./day, according to Sumi and Miyakawa; Abuharfeil et al., [31,32].

Group IV (treated group): was received the standard diet with sodium nitrite and pumpkin seed oil with the same previous doses.

Sodium nitrite and pumpkin seed oil were given orally by gastric tube. The medications were given for a period of 5 weeks. Pumpkin seed oil was administered 6 hours after Sodium nitrite. The experimental protocol was approved by the institutional animal care and use committee at the department of pharmacology, Faculty of medicine, Minia University.

At the end of the experimental period, 6 rats / group were injected with $0.5 \mathrm{mg} / \mathrm{kg}$ of $0.5 \%$ colichicine intraperitoneally 2 hours prior to sacrifing the animals to arrest the mitotic division at metaphase stage to investigate chromosomal abnormalities. All rats were anesthetized with ether and sacrificed by cervical dislocation. Two blood samples were suitably collected after scarification from each rat (6 non dosed colichicine rats) one for biochemical analysis and the other for comet assay. The whole liver and heart were dissected out. Bone marrow cells were collected from both femur of each rat (6 IP dosed colichicine rats) by aspiration.

\section{Biochemical Analysis}

The blood samples were centrifuged (centrifuge Jantezki, T30, Germany) at $4000 \mathrm{~g}$ for 10 minutes for serum collection. Sera were separated and freezed at $-80^{\circ} \mathrm{C}$ until biochemical analysis. Total antioxidant capacity (TAC) and serum lipids profile (cholesterol, triglycerides and high density lipoprotein (HDL)) were determined using colorimetric assay kit according to the manufacturer's instructions. Malondialdhyde (MDA) level as an indicator of lipid peroxidation was determined using the thiobarbituric acid method as described by Buege and Aust who measured the thiobarbituric acid reactive substances (TBARS) concentration [33].

\section{Preparation of Tissue Homogenates}

Specimens from liver and heart were homogenized separately in phosphate buffer solution (prepared by dissolving 8.01g NaCl, $0.20 \mathrm{~g} \mathrm{KCl}, 1.78 \mathrm{~g} \mathrm{Na}_{2} \mathrm{HPO}_{4}, 2 \mathrm{H}_{2} \mathrm{O}$ and $0.27 \mathrm{~g} \mathrm{KH}_{2} \mathrm{PO}_{4}$ in 1 liter of distilled water and $\mathrm{pH}$ was adjusted at 7.4) using homogenizer (Tri-R Stir-R homogenizer, Tri-R Instruments, Inc., Rockville Centre, NY). The ratio of tissue weight to homogenization buffer was 1:5. The homogenates were centrifuged at $5000 \mathrm{rpm}$ for 10 $\min$ at $4{ }^{\circ} \mathrm{C}$. The resulting supernatant was kept at $-80^{\circ} \mathrm{C}$ until assessment of cholesterol, triglycerides and HDL levels.

\section{Genotoxic Investigation}

DNA damage with comet assay: The comet assay can identify low levels of DNA damage in tissue samples either in vivo or in 
vitro (any type of cells) and can evaluate the protective effect of antioxidants/micronutrients to the genetic material [34].

The comet assay under alkaline conditions was done as described by Singh et al., [35] with some modifications according to Grover et al., [36]. Briefly, The cell were embedded in agarose coated slide, their lysis in alkaline buffer 1 hour at $4^{\circ} \mathrm{C}$ in dark, alkaline DNA unwinding occur, and finally electrophoresis at $25 \mathrm{~V} / 300$ $\mathrm{mA}$ for 30 minutes. Wash with neutralization buffer and staining with ethidium bromide. The extent of DNA damage was measured by quantitative method; measuring the tail length to measure DNA damage [37].

Chromosomal aberrations: Chromosome preparation from somatic cells (bone marrow cells) was performed as described by Alder [38]. Femoral bone marrow cells were collected in physiological saline solution $(0.9 \%)$ sodium chloride and centrifuged at $1200 \mathrm{RPM}$ at 10 minutes. After centrifugation, the supernatant was discarded and potassium chloride solution $0.56 \%$ was added to the sediment as hypotonic solution and incubator at $37^{\circ} \mathrm{C}$ for 30 minutes. The cells were fixed in cold fixative (3:1 methyl alcohol: glacial acetic acid). Centrifugation and fixation were done for three times. Few drops of cell suspension were dropped on clean cold slide which was dropped in 70\% ethanol. Alcohol was burnt on a burner to dry the slide.

After complete drying, slides were stained in 10\% Geimsa stain in Sorenson buffer for 30 minutes. 50 metaphase for each animal was examined and structural chromosomal aberrations were recorded.

\section{Statistical Analysis}

Data were expressed as mean \pm standard deviation (S.D.) of mean. The collected data was coded, tabulated and statistically analyzed using SPSS (Statistical Package for Social Sciences) program software version 20 .

The differences among treated groups were performed by oneway ANOVA test followed by Tukey - Kramar post hoc test for multiple comparisons. The difference of mean was considered statistically significant at a value of $\mathrm{P}<0.05$.

\section{Results}

\section{Biochemical Analysis}

Statistical analysis of serum TAC and MDA level are presented in Table 1. Sodium nitrite group showed significant reduction in serum TAC level that was associated with significant increase in MDA level as compared with control group. The pumpkin seed oil significantly prevented the effect of sodium nitrite; the treated group showed no significant differences in serum TAC and MDA levels with the control group. The pumpkin seed oil group showed slight changes in the levels of TAC and MDA but with no significant differences with the control group.

Lipid profile parameters in serum, liver and heart of the different groups are presented in Table 2, 3 and 4. Sodium nitrite caused significant increase in the levels of triglycerides and cholesterol, however, the level of HDL cholesterol showed significant reduction as compared to the normal control group in serum, liver and heart. Meanwhile, significant reductions in the levels of triglycerides and cholesterol with a significant increase in HDL were recorded in rats treated with pumpkin seed oil either alone or in combination with sodium nitrite as compared to sodium nitrite group in serum, liver and heart.

\section{DNA with comet assay}

Our experiment revealed significant increase in the tail length of DNA by comet assay in the sodium nitrite group as compared to the control group. Pumpkin seed oil treatment significantly reduce DNA damage, the treated group showed significant reduction in the DNA damage as compared with the sodium nitrite group but still significantly differ from the control group. Administration of Pumpkin seed oil alone had no significant changes in the tail length of DNA in comparison to the control group (Table 5) and (Figure 1).

\section{Chromosomal Aberrations}

We examined the genotoxic effect of sodium nitrite after oral administration of $100 \mathrm{mg} / \mathrm{kg} /$ day for 5 weeks on the examined cells taken from the bone marrow of the rats. The observed structural chromosomal abnormalities in the examined cells were gap, break, fragments, deletion and end to end (Figure 2). The mean values $\pm \mathrm{SD}$ of the frequency of structural chromosomal aberrations are presented in Table 6.

The data in Table 6 shows that $\mathrm{NaNO}_{2}$ induced a significant increase in the frequency of chromosomal aberrations in rats as compared to the control group. Sodium nitrite treated with pumpkin seed oil showed significant reduction in chromosomal aberrations in comparison to the sodium nitrite group but still significantly higher than the control group. No significant changes

Table 1. Effect of Sodium Nitrite and Pumpikin Oil and Their Combination on TAC and MDA in Rats.

\begin{tabular}{|c|c|c|}
\hline Groups & Serum TAC (m mol/L) & Serum MDA (n mol/ dL) \\
\hline Group I & $1.99 \pm 0.103$ & $203.04 \pm 8.20$ \\
\hline Group II & $2.14 \pm 0.163^{\mathrm{b}}$ & $210.74 \pm 13.62^{\mathrm{b}}$ \\
\hline Group III & $0.98 \pm 0.145^{\mathrm{a}}$ & $405.80 \pm 10.64^{\mathrm{a}}$ \\
\hline Group IV & $1.83 \pm 0.069^{\mathrm{b}}$ & $219.78 \pm 7.99^{\mathrm{b}}$ \\
\hline
\end{tabular}

Results represent the mean values \pm SD. $(n=6)$

${ }^{a}$ significant $(P<0.05)$ difference from normal control group,

${ }^{\mathrm{b}}$ significant $(P<0.05)$ difference from $\mathrm{NaNo}_{2}$ group. 
Table 2. Effect of Sodium Nitrite and Pumpikin Oil and Their Combination on Total Cholesterol in Serum, Heart and Liver in Rats.

\begin{tabular}{|c|c|c|c|}
\hline Groups & Serum $(\mathrm{mg} / \mathrm{dl})$ & Heart (mg/gm tissue) & Liver (mg/gm tissue) \\
\hline Group I & $70.06 \pm 11.51$ & $12.33 \pm 2.00$ & $7.17 \pm 2.21$ \\
\hline Group II & $73.97 \pm 11.66$ & $12.04 \pm 2.28$ & $7.37 \pm 2.53$ \\
\hline Group III & $95.59 \pm 5.43^{\mathrm{a}}$ & $17.16 \pm 0.79^{a}$ & $11.00 \pm 1.94^{\mathrm{a}}$ \\
\hline Group IV & $77.34 \pm 8.29^{\mathrm{b}}$ & $12.28 \pm 1.53^{\mathrm{b}}$ & $7.76 \pm 0.71^{a}$ \\
\hline
\end{tabular}

Table 3. Effect of Sodium Nitrite and Pumpikin Oil and Their Combination on Triglycerides in Serum, Heart and Liver in Rats.

\begin{tabular}{|c|c|c|c|}
\hline Groups & Serum $(\mathrm{mg} / \mathrm{dl})$ & Heart (mg/gm tissue) & Liver ( $\mathrm{mg} / \mathrm{gm}$ tissue) \\
\hline Group I & $54.20 \pm 7.83$ & $9.98 \pm 1.40$ & $7.01 \pm 2.00$ \\
\hline Group II & $56.03 \pm 7.90$ & $10.19 \pm 1.46$ & $6.58 \pm 2.18$ \\
\hline Group III & $81.27 \pm 7.63^{a}$ & $14.08 \pm 0.98^{a}$ & $12.91 \pm 2.91^{\mathrm{a}}$ \\
\hline Group IV & $66.80 \pm 8.15^{b}$ & $11.00 \pm 1.17^{\mathrm{b}}$ & $7.92 \pm 1.62^{b}$ \\
\hline
\end{tabular}

Table 4. Effect of Sodium Nitrite and Pumpikin Oil and Their Combination on HDL in Serum, Heart and Liver in Rats.

\begin{tabular}{|c|c|c|c|}
\hline Groups & Serum $(\mathbf{m g} / \mathbf{d l})$ & Heart (mg/gm tissue) & Liver (mg/gm tissue) \\
\hline Group I & $55.55 \pm 7.11$ & $10.38 \pm 0.91$ & $9.64 \pm 1.41$ \\
\hline Group II & $52.03 \pm 4.44$ & $10.69 \pm 1.20$ & $9.69 \pm 1.67$ \\
\hline Group III & $33.41 \pm 4.33^{\mathrm{a}}$ & $5.71 \pm 0.78^{\mathrm{a}}$ & $4.37 \pm 0.52^{\mathrm{a}}$ \\
\hline Group IV & $48.65 \pm 4.25^{\mathrm{b}}$ & $9.83 \pm 1.77^{\mathrm{b}}$ & $6.43 \pm 0.90^{\mathrm{ab}}$ \\
\hline
\end{tabular}

Results represent the mean values \pm SD. $(\mathrm{n}=6)$

${ }^{a}$ significant $(P<0.05)$ difference from normal control group,

${ }^{\mathrm{b}}$ significant $(P<0.05)$ difference from $\mathrm{NaNO}_{2}$ group.

Table 5. The Tail Length of DNA by Comet Assay in Sodium Nitrite and Pumpikin Oil and Their Combination Groups in Rats.

\begin{tabular}{|c|c|}
\hline Groups & Mean \pm SD \\
\hline Group I (control) & $13.67 \pm 1.75$ \\
\hline Group II (pumpkin seed oil) & $16.44 \pm 2.05^{\mathrm{b}}$ \\
\hline Group III (sodium nitrite) & $32.29 \pm 3.28^{\mathrm{a}}$ \\
\hline Group IV (treated) & $19.29 \pm 1.44^{\mathrm{ab}}$ \\
\hline
\end{tabular}

Results represent the mean values \pm SD. $(n=6)$

a significant $(P<0.05)$ difference from normal control group,

${ }^{\mathrm{b}}$ significant $(P<0.05)$ difference from $\mathrm{NaNo}_{2}$ group.

in the frequency of chromosomal abnormalities in the group administered pumpkin seed oil alone in comparable to the control group.

\section{Discussion}

Nitrite is a common contaminant present in natural water and the atmosphere [39]. It is also an essential antimicrobial food additive that prevents the growth of botulinum toxin and inhibits rancidity during food storage [7]. Nitrite is introduced to the environment from agricultural sources, the mishandling of inorganic fertilizers with the misuse of our natural resources that resulting in the disturbance of nitrogen cycles [1].
The biochemical analysis in the present study was done to investigate the oxidative stress induced by sodium nitrite after administration of $100 \mathrm{mg} / \mathrm{kg} /$ day for 5 weeks and evaluate the protective effect of pumpkin seed oil as an antioxidant. The results revealed significant decrease in the serum TAC level accompanied with significant increase in the serum MDA level in the sodium nitrite group as compared to the control group. Our result is in agreement with previous studies [40, 41]. Krishnamoorthy and Sangeetha revealed alteration in the level of lipid peroxidation and antioxidant enzymes after oral administration of sodium nitrite (300 $\mathrm{mg} / \mathrm{kg}$ ) for 30 days [42]. They contributed the cytotoxic effect of nitrite to the formation of nitric oxide (NO) and peroxynitrite from the nitrite. The peroxynitrite is a powerful oxidant that leads to oxidation of thiol groups and causes peroxidation. Patsoukis 
Figure 1. a: Tail length of DNA by comet assay of group I (control group). b: Tail length of DNA by comet assay of group II (pumpkin seed oil group). c: Tail length of DNA by comet assay of group III (sodium nitrite group). d: Tail length of DNA by comet assay of group IV (treated group).

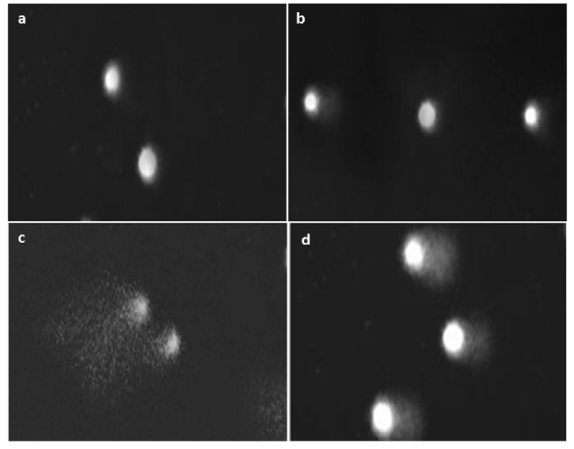

Figure 2. a: Normal metaphase spread from rat bone marrow of control group. b: metaphase spread from rat bone marrow of sodium nitrite intoxicated group showing gap. c: metaphase spread from rat bone marrow of sodium nitrite intoxicated group showing fragment. $\mathrm{d}$ : metaphase spread from rat bone marrow of sodium nitrite intoxicated group showing break. e: metaphase spread from rat bone marrow of sodium nitrite intoxicated group showing deletion. f: metaphase spread from rat bone marrow of sodium nitrite intoxicated group showing end to end.

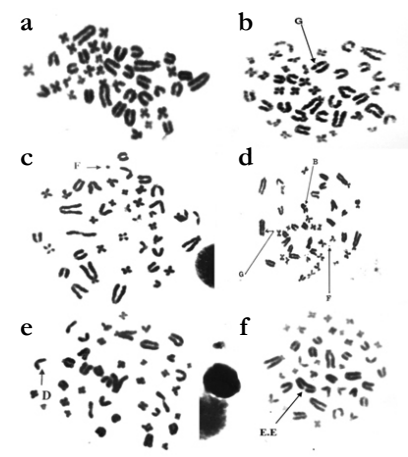

Table 6. Structural Chromosomal Aberrations in the Examined Cells Taken from the Bone Marrow in Sodium Nitrite and Pumpikin Oil and their Combination Groups in Rats.

\begin{tabular}{|c|c|c|c|c|c|c|}
\hline Groups & Gap & Break & Deletion & Fragment & End to end & Total \\
\hline Group I & $0.33 \pm 0.52$ & $0.50 \pm 0.83$ & $0.16 \pm 0.40$ & $0.50 \pm 0.55$ & $0 \pm 0.00$ & $1.50 \pm 1.64$ \\
\hline Group II & $0.50 \pm 0.84$ & $0.50 \pm 0.54$ & $0.33 \pm 0.52$ & $0.16 \pm 0.40$ & $0.33 \pm 0.81$ & $1.83 \pm 0.98^{\mathrm{b}}$ \\
\hline Group III & $3.16 \pm 0.75$ & $2.67 \pm 1.50$ & $1.83 \pm 0.76$ & $1.67 \pm 0.82$ & $1.83 \pm 1.47$ & $11.17 \pm 2.85^{\mathrm{a}}$ \\
\hline Group IV & $1.00 \pm 0.89$ & $1.33 \pm 1.21$ & $1.17 \pm 0.75$ & $0.83 \pm 0.74$ & $0.67 \pm 0.82$ & $5.00 \pm 2.37^{\mathrm{ab}}$ \\
\hline
\end{tabular}

Results represent the mean values \pm SD. $(n=6)$

${ }^{a}$ significant $(P<0.05)$ difference from normal control group, ${ }^{\text {b }}$ significant $(P<0.05)$ difference from $\mathrm{NaNO}_{2}$ group.

and Georgiou recorded that sodium nitrite generates free radicals in high levels that the cellular defense system cannot compensate and lead to oxidative stress and lipids peroxidation [43].

On the other hand, the treated group showed significant increase in the TAC level and reduction in the MDA level as compared with sodium nitrite group while there were no significant differences with the control group. The previous result indicates that pumpkin seed oil has antioxidant and antiradical effects which is in accordance with Xanthopoulou et al., and Nkosi et al., [44, 45].

This finding could be attributed to the composition of pumpkin seed oil. It is recognized that, vitamin E [46] and phenolic compounds [21] bind to free radicals and so inhibit the cell membrane oxidation and occurrence of lipid peroxidation. Also, the phytosterols have antioxidant activity and they can reduce LDL-cho- lesterol which leads to reduction of the lipid peroxidation [22]. Selenium in the pumpkin seed oil is included in the structure of GSH-Px enzyme which is directly incorporated in its antioxidant activity [47].

Squalene is composed of a high level of unsaturated aliphatic hydrocarbons that prevent oxidation of body lipids and has antioxidant activity against unsaturated fatty acids [23]. Furthermore, the essential fatty acids have inhibitory action on the cyclooxygenase pathway, and this assists in the antioxidant defense system [44]. The serum TAC and MDA levels in the pumpkin seed oil group showed minimal changes but did not differ significantly from the control group. This indicates that pumpkin seed oil does not affect the antioxidant defense system. It has been suggested that, the changes observed in the measured enzymes activity may be due to the action of pumpkin seed oil for elimination of free 
radicals under normal conditions [48].

Our results revealed significant increase in levels of cholesterol and triglycerides and decrease in level of HDL are in accordance with many previous investigators. Sherif and Al-Gayyar revealed significant increase in serum cholesterol, triglycerides after 12 weeks of sodium nitrite treatment $(80 \mathrm{mg} / \mathrm{kg})$ [7]. Moreover, previous investigators reported slight elevation of total cholesterol levels, and decrease of HDL-c concentration after high dietary nitrite $[49,50]$.

On the other hand, our results are in contrast with Helal et al., who revealed significant decrease in total cholesterol in heart tissue after sodium nitrite treatment for six months, while total cholesterol showed significant increase in serum but insignificant change in liver tissue after three and six months of sodium nitrite treatment [51]. Kostogrys et al., confirmed a part of our results; they noted that increasing dietary nitrite levels resulted in decreased serum HDL-c and increased serum triacyglycerols, while serum total cholesterol was significantly reduced [52].

Elevation in cholesterol and triglycerides levels in serum may be attributed to lipid peroxidation or the liberation of free fatty acids from the adipose tissue to the blood stream and raising the acetyl CoA level which enhance cholesterol synthesis. It has been reported that oxidative stress stimulates the influence of non-essential fatty acids that leads to increase of cholesterol and triglycerides levels in serum and tissues [53]. Oxidative stress has long been expected to have a significant role in the development of atherosclerosis.

Our results revealed that co-administration of pumpkin seed oil with sodium nitrite significantly prevented the alterations recorded in the levels of cholesterol, triglycerides and HDL-c in serum, liver and heart after sodium nitrite treatment. This result is in concordant with Barakat \& Mahmoud who proved the anti-atherogenic effect of pumpkin seed mixture; it resulted in a significant improvement in lipid parameters in plasma and liver of rats [54]. The presence of polyunsaturated fatty acids, $\beta$-carotene, phytosterols and tocopherols in seed mixture may play an important role in lowering blood cholesterol in human and rats [55]. Hyounjeong et al., reported that pumpkin has antiobesity effects and attributed that to its action as metabolic regulator of lipolytic and lipogenic pathways [56]. Moreover, it affects the lipid products synthesis and degradation.

It has been reported that antioxidants compensate the radicals of polyunsaturated fatty acids and disturb the chain reactions; hence they can inhibit lipid peroxidation [53]. The antioxidants have been supposed to act as antiatherogenic agents. They may be able to prevent the oxidative modification of LDL that result in the accumulation of cholesterol [57].

In this study, DNA damage by comet assay and chromosomal aberrations were done to investigate the genotoxic effect of sodium nitrite and whether the pumpkin seed oil can ameliorate this effect or not. The comet assay for DNA revealed significant increase in the tail length of DNA in the sodium nitrite intoxicated group in comparison to the control group. Our result is almost similar to the results obtained by Ohsawa et al., [58] and Sherif and AlGayyar who revealed DNA fragmentation after 12 weeks of 80 $\mathrm{mg} / \mathrm{kg}$ of sodium nitrite [59].
This has been explained by Ibrahim and Nassar who proved that reactive oxygen species, which are generated by $\mathrm{NaNO}_{2}$ causes genetic oxidation and fragmentation of DNA and other macromolecules [60]. Nitric oxide (free radicals) which is produced by sodium nitrite inhibits synthesis of DNA and arrest the cell cycle, therefore, DNA damage occurs.

Treatment with pumpkin seed oil significantly decreased DNA damage as compared with sodium nitrite intoxicated group but still significantly higher than the control group. There are multiple studies have been reported about the mechanisms of pumpkin seed oil for prevention of free radical generation and accordingly prevent DNA damage [21, 22]. Furthermore, the phenolic compounds in the pumpkin seed oil bind to metals as copper and iron that are incorporated in free radical-generating reactions as the Fenton reactions [61].

The genotoxic investigation in our study showed marked increase in the frequency of total structural chromosomal aberrations in the bone marrow cells of the rats administered sodium nitrite in comparison to the control group. Occurrence of chromosomal aberrations at the metaphase is due to molecular lesions in the DNA and they are considered as the cytotoxic effect of some chemicals [62].

Hence, our findings revealed the mutagenic effect of sodium nitrite and this is in agreement with Özen et al., who revealed significant increase in chromosomal aberrations after administration of $20 \mathrm{mg} / \mathrm{kg}$ sodium nitrite for 8 months [41].

On the other hand, administration of sodium nitrite and pumpkin seed oil showed significant reduction in the frequency of total chromosomal aberrations in comparable to sodium nitrite group. The effect of pumpkin seed oil may be due to its antioxidant action, prevention of free radicals and reduction of DNA damage as described previously. The balance between the oxidative and anti-oxidative systems is the main factor to keep the cellular health. Any disturbance in this balance leads to cellular degeneration and death [41]. According to the authors` knowledge, there is no previous studies have investigated the valuable effect of pumpkin seed oil for prevention and/or reduction of toxicity induced by sodium nitrite.

\section{Acknowledgement}

The authors thank the National Research Center, Dokki, Giza, Egypt, for the use of facilities to execute this research. This research received no specific grant from any funding agency in the public, commercial, or not-for-profit sectors.

\section{Conclusion}

Chronic exposure to high level of sodium nitrite leads to biochemical effect, DNA damage and chromosomal aberrations. The pumpkin seed oil can ameliorate the toxic effect induced by sodium nitrite due to its antioxidant, antimutagenic and antifree radicals effects as it contains high amounts of antioxidant vitamins as $\alpha$ - and $\gamma$-tocoferol, $\beta$ carotene and vitamin E. Moreover, it contains phenolic compounds such as vanillic acid, tyrosol and vanillin and high levels of selenium and lutein. Hence, we can use 
the pumpkin seed oil as a prophylaxis against $\mathrm{NaNO}_{2}$ toxicity, taking into consideration the dose and duration of treatment.

\section{References}

[1]. Moorcroft MJ, Davis J, Compton RG (2001) Detection and determination of nitrate and nitrite: a review. Talanta. 54(5): 785-803.

[2]. Nossaman VE, Nossaman BD, Kadowitz PJ (2010) Nitrates and nitrites in the treatment of ischemic cardiac disease. Cardiol Rev. 18(4): 190-197.

[3]. Omar SA, Webb AJ (2014) Nitrite reduction and cardiovascular protection. J Mol Cell Cardiol. 73: 57-69.

[4]. Baek JH, Zhang X, Williams MC, Hicks W, Buehler PW, et al., (2015) Sodium nitrite potentiates renal oxidative stress and injury in hemoglobin exposed guinea pigs. Toxicology. 333: 89-99.

[5]. Sun J, Aoki K, Wang W, Guoa A, Misumi J (2006) Sodium nitrite-induced cytotoxicity in cultured human gastric epithelial cells. Toxicol In Vitro. 20(7): 1133-1138

[6]. Hunter CJ, Dejam A, Blood AB, Shields H, Kim-Shapiro DB, et al., (2004) Inhaled nebulized nitrite is a hypoxia-sensitive NO-dependent selective pulmonary vasodilator. Nat Med. 10(10): 1122-1127.

[7]. Sherif IO, Al-Gayyar, MM (2015) Cod liver oil in sodium nitrite induced hepatic injury: does it have a potential protective effect? Redox Rep. 20:1116.

[8]. Bonnell A (1995) Nitrate concentrations in vegetables. Proceedings of the International Workshop on Health Aspects of Nitrates and its Metabolites (Particularly Nitrite). Netherlands: Council of Europe Press. 11-20.

[9]. Sindelar JJ, Milkowski, AL (2012) Human safety controversies surrounding nitrate and nitrite in the diet. Nitric Oxide. 26(4): 259-266.

[10]. EFSA (2008) Nitrate in vegetables. Scientific opinion of the panel on contaminants in the food chain. EFSA J. 689: 1-79.

[11]. Attof R, Magnin C, Bertin-Maghit M, Olivier L, Tissot S, et al., (2006) Methemoglobinemia by cerium nitrate poisoning. Burns. 32(8): 1060-1061.

[12]. Santamaria P (2006) Nitrate in vegetables: toxicity, content, intake and EC regulation (review). J Sci Food Agric. 86(1): 10-17.

[13]. Hassan HA, El-Agmy SM, Gaur RL, Fernando A, Raj MH, et al., (2009) In vivo evidence of hepato- and reno-protective effect of garlic oil against sodium nitrite-induced oxidative stress. Int J Biol Sci. 5(3): 249-255.

[14]. Yamada K, Yamamiya I, Utsumi H (2006) In vivo detection of free radicals induced by diethylnitrosamine in rat liver tissue. Free Radic Biol Med. 40(11): 2040-2046.

[15]. Salama MF, Abbas A, Darweish MM, El-Hawwary AA, Al-Gayyar MM (2013) Hepatoprotective effects of cod liver oil against sodium nitrite toxicity in rats. Pharm Biol. 51(11): 1435-1443.

[16]. Tang Y, Jiang H, Bryan NS (2011) Nitrite and nitrate: cardiovascular riskbenefit and metabolic effect. Curr Opin Lipidol. 22(1): 11-15.

[17]. Kozisek F (2007) Influence of nitrate levels in drinking water on urological malignancies: a community-based cohort study. BJU Int. 99(6): 1550-1551.

[18]. Procida G, Stancher B, Catenia F, Zacchigna M (2013) Chemical composition and functional characterisation of commercial pumpkin seed oil. J Sci Food Agric. 93(5): 1035-1041

[19]. Rezig L, Chouaibi M, Msaada K, Hamdi S (2012) Chemical composition and profile characterisation of pumpkin (Cucurbita maxima) seed oil. Ind Crop Prod. 37: 82-87.

[20]. Stevenson DG, Eller FJ, Wang L, Jane JL, Wang T, et al., (2007) Oil and tocopherol content and composition of pumpkin seed oil in 12 cultivars. J Agric Food Chem. 55(10): 4005-4013.

[21]. Andjelkov M, Camp JV, Trawka A, Verhe R (2010) Phenolic compounds and some quality parameters of pumpkin seed oil. Eur J Lipid Sci Tech. 112(2): 208-217.

[22]. Nyam KL, Tan CP, Lai OM, Long K, Man YB (2009) Physicochemical properties and bioactive compounds of selected seed oil. LWT-Food Sci Technol. 42: 1396-1403.

[23]. Ryan E, Galvin K, O'Connor TP, Maguire AR, O'Brien NM (2007) Phytosterol, squalene, tocopherol content and fatty acid profile of selected seeds, grains, and legumes. Plant Foods Hum Nutr. 62(3): 85-91.

[24]. Caili F, Huan S, Quanhong L (2006) A review on pharmacological activities and utilization technologies of pumpkin. Plant Foods Hum Nutr. 61(2): 73-80

[25]. Al-Zuhair H, Abd El-Fattah AA, Abd El Latif HA (1997) Efficacy of simvastatin and pumpkin-seed oil in the management of dietary-induced hypercholesterolemia. Pharmacol Res. 35(5): 403-408

[26]. Fruhwirth GO, Hermetter A (2007) Seeds and oil of the Styrian oil pumpkin: Components and biological activities. Eur J Lipid Sci Technol. 109(11): $1128-1140$

[27]. Fahim AT, Abd-el Fattah AA, Agha AM, Gad MZ (1995) Effect of pumpkin-seed oil on the level of free radical scavengers induced during adjuvant- arthritis in rats. Pharmacol Res. 31: 73-79.

[28]. Elfiky SA, Elelaimy IA, Hassan AM, Ibrahim HM, Elsayad RI (2012) Protective effect of pumpkin seed oil against genotoxicity induced by azathioprine. J Basic Appl Zool. 65: 289-298.

[29]. Matsuyama M, Yoshimura R, Mitsuhashi M, Hase T, Tsuchida K, et al., (2004) Expression of lipoxygenase in human prostate cancer and growth reduction by its inhibitors. Int J Oncol. 24(4): 821-827.

[30]. Eraslan G, Kanbur M, Aslan O, Karabacak M (2013) The antioxidant effects of pumpkin seed oil on subacute aflatoxin poisoning in mice. Environ Toxicol. 28(12): 681-688.

[31]. Sumi Y, Miyakawa M (1983) Susceptibility of germ-free rats to the hepatotoxic effects of dimethylnitrosamine or dimethylamine plus sodium nitrite administered orally. Cancer Res. 43(6): 2942-6.

[32]. Abuharfeil N, Sarsour E, Hassuneh M (2001) The effect of sodium nitrite on some parameters of the immune system. Food Chem Toxicol. 39(2): 119124.

[33]. Buege JA, Aust SD (1987) Microsomal lipid peroxidation. Methods Enzymol. 52: 302-310.

[34]. Heaton PR, Reed CF, Mann SJ, Ransley R, Stevenson J, et al., (2002) Role of dietary antioxidants to protect against DNA damage in adult dogs. J Nutr. 132(2): 1720S-1724S

[35]. Singh NP, McCoy MT, Tice RR, Schneider EL (1988) A simple technique for quantitation of low levels of DNA damage in individual cells. Exp Cell Res. 175(1): 184-191.

[36]. Grover P, Banu BS, Devi KD, Begum S (2001) In vivo genotoxic effects of mercuric chloride in rat peripheral blood leucocytes using comet assay. Toxicology. 167(3): 191-197.

[37]. Collins AR (2004) The comet assay for DNA damage and repair: principles, applications, and limitations. Mol Biotechnol. 26(3): 249-261

[38]. Adler ID (1984) Cytogenetic Tests in Mammals. Mutagenicity Testing: a Practical Approach. Oxford, Washington: IRL Press. 275-306.

[39]. Manzoori J, Sorouraddin MH, Haji-Shabani AM (1998) Spectrophotometric determination of nitrite based on its catalytic effect on the oxidation of carminic acid by bromate. Talanta. 46(6): 1379-1386.

[40]. Abu Aita NA, Mohammed FF (2014) Effect of marjoram oil on the clinicopathological, cytogenetic and histopathological alterations induced by sodium nitrite toxicity in rats. Global Vet. 12(5): 606-616.

[41]. Özen H, Kamber U, Karaman M, Gül S, Atakişi E, et al., (2014) Histopathologic, biochemical and genotoxic investigations on chronic sodium nitrite toxicity in mice. Exp Toxicol Pathol. 66(8): 367-375.

[42]. Krishnamoorthy P, Sangeetha M (2008) Hepatoprotective effect of vitamin $\mathrm{C}$ on sodium nitrite-induced lipid peroxidation in albino rats. Indian J Biochem Bio. 45(3): 206-208.

[43]. Patsoukis N, Georgiou CD (2007) Effect of sulfite-hydrosulfite and nitrite on thiol redox state, oxidative stress and sclerotial differentiation of filamentous phytopathogenic fungi. Pestic Biochem Physiol. 88(2): 226-235.

[44]. Xanthopoulou MN, Nomikos T, Fragopoulou E, Antonopoulou S (2009) Antioxidant and lipoxygenase inhibitory activities of pumpkin seed extracts. Food Res Int. 42(5-6): 641-646.

[45]. Nkosi CZ, Opoku AR, Terblanche SE (2005) Effect of pumpkin seed $(\mathrm{Cu}-$ curbita pepo) protein isolate on the activity levels of certain plasma enzymes in CCl4-induced liver injury in low-protein fed rats. Phytother Res. 19(4): 341-345.

[46]. Zadák Z, Hyspler R, Tichá A, Hronek M, Fikrová P, et al., (2009) Antioxidants and vitamins in clinical conditions. Physiol Res. 58 (1): S13-17.

[47]. Halliwell B (2007) Biochemistry of oxidative stress. Biochem Soc Trans. 35(5): $1147-1150$

[48]. Zuhair HA, Abd El-Fattah AA, El-Sayed MI (2000) Pumpkin-seed oil modulates the effect of felodipine and captopril in spontaneously hypertensive rats. Pharmacol Res. 41(5): 555-563.

[49]. Duntas LH (2002) Thyroid disease and lipids. Thyroid. 12(4): 287-293.

[50]. Luboshitzky R, Aviv A, Herer P, Lavie L (2002) Risk factors for cardiovascular disease in women with subclinical hypothyroidism. Thyroid. 12(5): $421-425$.

51]. Helal EGE, Zahkouk SA, Mekawy HA (2000) Effect of some food colours (synthetic and natural products) on liver and kidney functions of young albino rats. Egypt J Hosp Med. 1: 103-113.

[52]. Kostogrys RB, Zahkouk SA, Mekawy HA (2006) Nitrites affect thyroid status and serum lipoproteins in wistar rats. Pol J Food Nutr Sci. 15/56(3): 353-358.

[53]. Sanmugapriya E, Venkataraman S (2006) Studies on hepatoprotective and antioxidant actions of Strychnos potatorum Linn. seeds on CCl 4-induced acute hepatic injury in experimental rats. J Ethnopharmacol. 105(1-2): 15460 .

[54]. Barakat L AA, Mahmoud RH (2011) The antiatherogenic, renal protective and immunomodulatory effects of purslane, pumpkin and flax seeds on hypercholesterolemic rats. N Am J Med Sci. 3(9): 411-417. 
[55]. ElAdawy T, Taha K (2001) Characteristics and composition of different seed oils and flours. Food Chem. 74(1): 47-54.

[56]. Hyounjeong C, Haekwan E, Kyoungcheol P, Kim SH, Park JE, et al., (2007) A water-soluble extract from Cucurbita moschata shows antiobesity effects by controlling lipid metabolism in a high fat diet-induced obesity mouse model. BBRC. 359(3): 419-425.

[57]. Suzuki H, Kurihara Y, Takeya M, Kamada N, Kataoka M, et al., (1997) A role for macrophage scavenger receptors in atherosclerosis and susceptibility to infection. Nature. 386 (6622): 292-296.

[58]. Ohsawa K, Nakagawa SY, Kimura M, Shimada C, Tsuda S, et al., (2003) Detection of in vivo genotoxicity of endogenously formed N-nitroso compounds and suppression by ascorbic acid, teas and fruit juices. Mutat Res. 539(1-2): 65-76

[59]. Sherif IO, Al-Gayyar MM (2013) Antioxidant, anti-inflammatory and hepatoprotective effects of silymarin on hepatic dysfunction induced by sodium nitrite. Eur Cytokine Netw. 24:114-121

[60]. Ibrahim SS, Nassar NN (2008) Diallyl sulfide protects against N-nitrosodiethylamine- induced liver tumorigenesis: role of aldose reductase. World J Gastroenterol. 14(40): 6145-6153.

[61]. Letelier ME, Sanchez-Jofre S, Peredo-Silva L, Cortés-Troncoso J, AracenaParks P (2010) Mechanisms underlying iron and copper ions toxicity in biological systems: Pro-oxidant activity and protein-binding effects. Chem Biol Interact. 188(1): 220-227.

[62]. Kjuus H, Hansteen IL, Ryberg D, Goffeng LO, Ovrebø S, et al., ( 2005) Chromosome aberrations in tunnel workers exposed to acrylamide and Nmethylolacrylamide. Scand J Work Environ Health. 31(4): 300-306. 